\title{
Antioxidant and Antimicrobial Properties of Spray- Dried and Freeze-Dried Powders of Camu-Camu (Myrciaria dubia Mc. Vaugh)
}

\author{
Alice Fujita (I), Volnei Brito Souza (II), Carmen Silvia Favaro- \\ Trindade (II), Bernadette Dora Gombossy de Melo Franco (III), \\ Maria Ines Genovese (I)
}

(I) USP - Laboratory of Food Bioactive Compounds, Food and Experimenta (University of São Paulo, 05508-900 São Paulo - SP, Brazil), (II) FZEA - Laboratory of Food Engineering, Faculty of Zootechnics and F (University of São Paulo, Pirassununga, São Paulo)

\section{Resumo}

Bioactive compounds such as phenolics and ascorbic acid are abundant in camu-camu (Myrciaria dubia Mc. Vaugh) and display both antioxidant and antimicrobial activities. This study aimed to evaluate the effect of the spray-drying process, using maltodextrin or arabic gum as carrier agents, in relation to the content of bioactive compounds and, antioxidant and antimicrobial capacities of two different commercial camu-camu pulps. One sample was from Sao Paulo and the other from Amazonas. A 32 design of response surface methodology (RSM) was used to evaluate the impact of carrier agent on total phenolics, ascorbic acid and proanthocyanidins contents, in vitro antioxidant capacity and antimicrobial activity. The use of the lowest concentration of carrier agents (6\%) in spray-drying resulted in the lowest losses of bioactive compounds and, consequently, the highest antioxidant and antimicrobial activities than the use of higher concentrations (12 and 18\%). Overall, the inlet air temperature range investigated had a lower impact on the variables studied than the concentration of the carrier agent. Lyophilization highly impacted bioactive-compound-related antioxidant and antimicrobial activities. On the other hand, spray-drying led to over 50\% reduction in total phenolics and ascorbic acid contents when compared to that of fresh pulp.Despite this, the

\footnotetext{
Referência:

Alice Fujita, Volnei Brito Souza, Carmen Silvia Favaro-Trindade, Bernadette Dora Gombossy de Melo Franco, Maria Ines Genovese. Antioxidant and Antimicrobial Properties of Spray-Dried and Freeze-Dried Powders of Camu-Camu (Myrciaria Dubia Mc. Vaugh). In: Anais do $12^{\circ}$ Congresso Latinoamericano de Microbiologia e Higiene de Alimentos - MICROAL 2014 [= Blucher Food Science Proceedings, num.1, vol.1]. São Paulo: Editora Blucher, 2014.

DOI 10.5151/foodsci-microal-337
} 
content of bioactive compounds in camu-camu powders was still much higher than that of others fruits. Freeze-dried and spray-dried powders produced with $6 \%$ of arabic gum at $120{ }^{\circ} \mathrm{C}$ and $150{ }^{\circ} \mathrm{C}$ were more effective Staphylococcus aureus ATCC 2913 inhibitors than ampicillin. In conclusion, camu-camu spray-dried powders could represent excellent food bioactive ingredients with antioxidant and antimicrobial properties and also, could be used as an alternative for designing functional food.

Palavras-Chave: antimicrobiano, antioxidantes, compostos fenolicos Agência de Fomento: $\mathrm{CNPq}$ 